\title{
The Cult of Quality: White Eugenics and Black Responses in the United States, 1900-1934
}

\author{
Matthew Aron Ginther*
}

\begin{abstract}
This paper focuses on the theory of eugenics and how it was adopted and subverted by black intellectual figures when institutionalized sterilizations were based upon class. The cornerstone of the eugenics theory was based in biological determinism and assumptions of genetic heritability. For black leaders, W.E.B. Du Bois in particular, the early plight for racial legitimacy rested on eugenics and, while morally questionable, strengthening the black community was an attempt to counteract white assumptions. Thus, 'black eugenics' should not immediately be condemned as an outright failure but should be regarded as an earnest attempt for civil rights. As such, it should not be forgotten and should be recognized as part of the broader framework for African American liberation.
\end{abstract}

Keywords: W.E.B. Du Bois, United States history, race, racism, eugenics, civil rights

In 1912, Howard University, one of America's premier black universities, offered their students course options on eugenics. It was the first year that Howard taught eugenics and aimed to present the inherent contradictions of eugenics regarding racial hierarchy. ${ }^{1}$ Twelve years prior, Dr.

${ }^{1}$ Gregory Michael Dorr, Segregation's Science: The American

Eugenics Movement and Virginia, (Charlottesville: of

Virginia, 2008), 98.
Paul Brandon Barringer, eugenicist and self-professed "scientific Redeemer," piece, "The American Negro: His Past and Present," that African Americans held a hereditary desire to return to their natural "savage" state of being. He borrowed this concept from Ernst Haeckel's doctrine of recapitulation, which argued, "every organism retraces all the evolutionary stages

*Department of History, College of Arts and Science, University of Saskatchewan, Saskatoon, SK, Canada

Correspondence: ginther.matthew@gmail.com 
that its ancestry passed through to assume its present form." ${ }^{\prime 3}$ The abolition of the "controlled environment of slavery" meant a pending racial apocalypse if nothing was to be done to quell the "black beast rapist." Barringer, using eugenics as his guide, saw the solution as returning race relations back to the "old relations in feeling that existed between the races at the close of the [Civil] war." ${ }^{14}$ This ideology called for the political disenfranchisement of blacks and for black education to be focused on making "law abiding laborers and artisans." In restoring the old status quo, racial harmony would follow; "the white man [would be saved] from barbarism by reclaiming the savage to whom he is inseparably tied. ${ }^{\prime 5}$ Barringer became an overnight sensation for his thesis and came to represent the scientific racism of the Progressive Era for his "liberal" attitude towards African American education. ${ }^{6}$

Eugenics was a theory that held physical and behavioral traits as being quantifiable in genes and that these genes were both biologically and environmentally determined and irreversible. Eugenicists and lawmakers during the Progressive Era of the United States (18gos 1920s) sought to encourage "superior" genes through selective sexual reproduction and to pass sterilization laws towards those deemed "unfit": primarily the "criminally insane" and the mentally defective, and people of low IOs, including the illiterate. There was often a racial component tied to eugenics as it was feared that the "pure" AngloSaxon would be "outbred" by new immigrants from Central and Eastern Europe. In the American South, universal equilibrium, governed by "self-directed human heredity and breeding," promised to liberate the United States from its racial nadir. It codified long-standing racial prejudices as natural and justified. Eugenics gave white supremacy and the "cognitive inferiority of the lower races" a new foundation within the realm of an objective scientific truth. For the time, eugenics was considered a credible science, a populist movement and the pinnacle of European thought and progress. However, far from any tangibly-defined

\footnotetext{
3 Ibid., 22.

${ }^{4}$ Paul Brandon Barringer, "The American Negro: His Past and Present," (1900), quoted in Dorr, Segregation's Science, 22.

${ }^{5}$ Ibid.

${ }^{6}$ Dorr, Segregation's Science, 22-23.
}

notion of "progress," eugenics was a thinly-veiled siren's call settled on the preservation of the pre-existing white hegemony at the expense of anything that upset its ranks.

Historian Gregory Dorr argues the eugenics movement gave a moral and scientific justification for racial biases in the American South. Furthermore, he argues that the science was attractive even for black Americans, who used their intellect to disprove its veracity, and for middleclass African American intellectuals, such as W.E.B. Du Bois, who used it as a science of exclusion within their own community. Although Dorr looks exclusively at Virginia, he shows that, even amongst African Americans, the popular eugenic science resonated as a meaningful, progressive approach to population control. My research builds on this idea of "progressive" eugenics in a twofold process. The first is to contextualize eugenics in how white Americans saw themselves and likewise, how white southerners viewed African-Americans via scientific racism; second is to critically analyze the response of black intellectuals' use of eugenics in constructed narratives of "racial uplift" in both its strengths and weaknesses. I wish to establish this period in African-American history as part of a broader civil rights struggle, and in doing so I wish to point out a legacy of black agency and resistance, and that it was neither uniform nor equalitarian in its approach, as exemplified by divisions in class. Lastly, and of special note, I infer resistance as an integral part in the creation of identity by the oppressed.

\section{'White' Eugenics: The scientific myth of Anglo-American supremacy}

As eugenics was the science of progress, Dr. Paul Barringer and other white eugenicists felt it was their duty to prevent "race suicide," the extinction of the 'white race,' as either brought through miscegenation or a boiling of race-based conflict. ${ }^{7}$ African-Americans made up 40 percent of the South's population so this demographic could not be safely ignored by Southern eugenicists. ${ }^{8}$ It was a matter of economic, social, and biological security for black racial development to be congruent with "God's natural law." Failing to do so would "either carry the South [backwards]

\footnotetext{
${ }^{7}$ Dorr, Segregation's Science, 38.

${ }^{8}$ Ibid., 44 .

${ }^{9}$ Ibid., 32.
} 
or... demand as the price of progress an expenditure of energy on the part of whites which no people can endure." This sentiment often implicitly conveyed whites' fear of a race war. ${ }^{10}$ Black professionals, lawyers, and doctors all posed a threat by going against natural law. The "social menace" they posed was that of breaking racial stereotypes and inhabiting positions that previously were strictly whiterun. One Barringer supporter was more worried about what became of black men born after the "stabilizing" force of slavery and resolved that only "much hemp and lead will be required to keep them in bounds." The South, it feared, threatened to tear itself apart if nothing was to be done to resolve this "Negro problem." ${ }^{11}$

In popularizing eugenics for the American public, eugenicists saw themselves as spreading the word of God. Religion was compatible with science through eugenics because God had, through human devices, allowed people to "make their own revelations" on biological reality. ${ }^{12}$ Eugenicists believed scientific knowledge drew them closer to God and the "divine purpose and governance" that befell upon them to better themselves. ${ }^{13}$ Eugenics was taken on the road to proselytize this new marriage between science and religion. Families were encouraged to participate in "Fitter Families" contests to gauge their hereditary value. Families deemed fit by a medical examiner received a medal inscribed with Psalms 16.6, "Yea, I have a goodly heritage. ${ }^{14}$ The strengthening of scientific discovery by latching it onto religion made it insurmountable for the majority of Christians to reject eugenics without going against their own value system. Positively, figures like Barringer saw themselves as good Christians who did not see their own prejudices as going against morality. Southerners applied "racial responsibility" towards black Americans, echoing centuries of racial baggage now under the scope of eugenics.

\footnotetext{
${ }^{10}$ Ibid., 44.

${ }^{11}$ Ibid., 45 .

${ }^{12}$ Steven Selden, Transforming Better Babies into Fitter Families: Archival Resources and the History of the American Eugenics Movement, 1908-1930. (Proceedings of the American Philosophical Society, 2005), 204.

${ }^{13}$ Dorr, Segregation's Science, 88.

${ }^{14}$ Selden, Better Babies, 205.
}

The politics of race-based violence, primarily lynchings, rested partially on eugenics. Barringer impressed on the public justification for long-standing racial mistreatment that outsiders had long thought to be immoral. Science, the objective guardian of truth, proved white Southerner's fear of the "black beast rapist." The rise in black crime post-slavery was verified to be a sign of growing mental degeneration in African Americans. ${ }^{15}$ One study by biologist Ivey Foreman Lewis had "proven" that there was considerable difference in brain structures among races. African Americans were especially emotional and were more prone to engage in 'rapist' behavior:

Primarily affectionate, immensely emotional, and then sensual and under stimulation passionate. There is love of ostentation, and capacity for melodious articulation; there is undeveloped artistic power and taste-Negroes make good artisans, handicraftsmen-and there is instability of character incident to lack of self-control, especially in connection with the sexual relation; and there is lack of orientation, or recognition of position and condition of self and environment, evidenced by a peculiar bumptiousness, so called, that is particularly noticeable. ${ }^{16}$

In an ever more absurdist fashion, Lewis had also determined that the natural posture of African Americans was that of "quadrupedia." He furthered "blacks walked upright as a force of will." Obviously, the black race was an uncivilized, degenerate people weighed down by "fifty centuries of historically recorded savagery." By way of scientific "fact," the South imposed further legal sanctions on the social and economic mobility of black Americans. ${ }^{17}$

\section{Resistance in the Classroom: Thomas Wyatt Turner and Howard University}

If this was the domineering climate of science as objective truth, then adding eugenics to Howard's curriculum was ostensibly an ill-conceived move. Howard, however, gained

$$
\begin{aligned}
& { }^{15} \text { Dorr, Segregation's Science, } 139 . \\
& { }^{16} \text { Ibid., 78-79. } \\
& { }^{17} \text { Ibid., } 21 .
\end{aligned}
$$


a new academic addition: Thomas Wyatt Turner, a new face in the emerging field of "black eugenics," was enrolled to teach the university's emergent field. Turner's Roman Catholic background and ex-slave parents vested in him a desire to counter the mainstream perceptions of black Americans within higher education. Although students were told to "define Eugenics [and] explain how society may be helped by applying eugenic laws," Turner posited that race was a non-factor in passing qualitative hereditary traits. "Defectives" could be found in every race and it was the obligation of each race to "eliminate" or out-breed the "undesirables of their population." As such, Turner was revolutionary in that he subverted the expectations of white eugenicists and put forth a counter-hypothesis that directly challenged their authority.

Turner's exposure to eugenic theory was through Charles Davenport, one of America's foremost eugenicists and founder of the Eugenics Record Office. After having had a falling out with Davenport, presumably the result of Davenport's own racism, Turner had refined eugenics to be more applicable to African Americans such as himself. Turner revolutionarily stated that it was the environmental conditions a person lived under that held crucial sway in their success or failure. While influential figures like Barringer had argued along similar lines, Turner had pushed for realized racial improvement. Poverty was a sin and higher education would bring the salvation of African Americans. However, Turner, being steeped in the eugenic rhetoric of his time, had to admit "the sociologist ... must be primarily a biologist. ${ }^{118}$ Heredity will still determine traits passed down, but whereas other mainline eugenicists had refused to acknowledge environment as being more important than heredity, Turner had made eugenics accessible to black Americans as a viable form of racial empowerment. By improving their environment, African Americans could claim as having capable heredity. It was an acknowledgement that systematic racism and poverty was a means of white control on African Americans but it still placed the onus on the individual to overcome it. If the individual fought and won against their environment then it ensured that their children, through heredity, gained an advantage amongst their peers. ${ }^{19}$

${ }^{18}$ Thomas Wyatt Turner, "The Biological Laboratory and Human Welfare," Howard University Record (January 1924), 4, quoted in Dorr, Segregation's Science, 101.

${ }^{19}$ Dorr, Segregation's Science, 99-101.
Turner preached racial harmony between whites and blacks, although whites may have interpreted his dissatisfaction with the status quo, as many African Americans were, as a harbinger of future racial strife. While his white "colleagues" urged for a racial hierarchy with African Americans on the bottom of that hierarchy, Turner believed that egalitarianism between races would generate "genuine respect" and "[reinforced] one's respectful reverence of personality among men." Turner had gone so far from mainstream eugenic discourse as to proclaim that humanity is "truly of one flesh, with a common parentage." Racial biology was without merit and did not deserve Turner's acknowledgement as a legitimate science. Despite the tense racial animosity that eugenics fuelled through racial violence and legislation, such as the antimiscegenation Racial Integrity Act of 1924, Turner had felt at the time of writing that science was nearing its apex in bringing about "universal brotherhood." ${ }^{20}$ The eugenic creed, "You are your brother's keeper! Your brothers are the human race, ${ }^{\prime 21}$ was taken more seriously across racial lines by Turner and subsequent African American intellectuals. Turner was the first to "humanize" the eugenic science by incorporating environmental and racial sensitivity into the biological/heredity equation.

Turner's interpretation of eugenics had expanded the "value hierarchy" ${ }^{22}$ that was intrinsically linked with it. The belief that the "innate" abilities of African Americans were beneath that of whites was seemingly becoming unglued. Appeals that the "very nationhood" of "Old American ideals" would be corrupted and forever lost if African Americans went outside their natural station had little effect in deterring their involvement in higher education. Education, and who was to receive it, was the battlefield for the well being of the nation. Samuel Mitchell, a famed educator, wrote that education "represents a structural process in society ... the latent potency that will create industries, uplift the masses, adjust racial difference, and regain political prestige..$^{\prime 23}$ If the African American

\footnotetext{
${ }^{20}$ Ibid., 102-104.

${ }^{21}$ Ibid., 2.

${ }^{22}$ Gerald V. O'Brien, Framing the Moron: The Social Construction of Feeble-mindedness in the American Eugenic Era, (Manchester: Manchester University Press, 2013): 132.
}

${ }^{23}$ Dorr, Segregation's Science, 50-52. 
community was to survive economically, politically, and socially, it had to become educated or else it risked entering a "second slavery" by means of ignorance and poverty. ${ }^{24}$ Turner's thesis, while symbolizing a hopeful utopia, remained at its core a problematic example of class determining a person's worth, namely that the majority of African-Americans will need "rescued" by an educated middle-class elite.

\section{The Publications of W.E.B. Du Bois: Crisis and the framework for a middle- class ideal on racial uplift policy}

Historian, activist, and National Association for the Advancement of Colored People (NAACP) co-founder, W.E.B. Du Bois was boastful toward his ability to convey the articulation of black consciousness. Du Bois agreed with eugenicists in that blacks posed the greatest number of "feebleminded" persons, perhaps more so than Turner ever did, but was aligned with Turner in reasoning that nurture, rather than nature, was to blame for black American "deficiencies." ${ }^{25}$ Du Bois conjured the African slave past in exclaiming the "heritage of moral iniquity" ${ }^{\prime 26}$ and abuse by "white adulterers" ${ }^{27}$ had bred into African American culture a shortage of "brains, efficiency, or beauty. ${ }^{28}$ Du Bois viciously attacked the former institution of slavery as well as the racial discrimination of his own time as limiting black people's potential. The extinction of African Americans resulted from the continued state of servitude to whites, to which Du Bois felt African Americans could remedy through economic security and higher education. Eugenics took a turn from "racial essentialism to intellectual elitism" in Du Bois writings. ${ }^{29}$ His countless contributions to periodicals and to the NAACP's newspaper publication, The Crisis, were the mouthpiece for Du Bois to articulate black eugenics on a mass scale that Turner did not have access to. Black eugenics was, to be sure, meant for the middle-class black community; by only having secured 35,000 subscriptions in 1915 in its then five-year run, The Crisis was not reaching the majority of African Americans. ${ }^{30}$ Many black Americans did not hear Du Bois speak or read his writing, either due to their own limitations or logistical obstacles, but his concentrated effort on "racial uplift" dialogue set him far apart from his white contemporaries.

The Crisis was founded by Du Bois and became his pulpit to propagate his racial uplift doctrine of the "Talented Tenth." The Talented Tenth were the "exception" ${ }^{131}$ from "the Mass of ignorant Negroes"; $;{ }^{32}$ the Tenth were locked in having to counter racial arguments about their own race's inferiority, while bettering the black race. Du Bois did not disagree with popular stereotypes of black criminality and laziness; he viewed their behavior through the lens of popular science and eugenics. Du Bois argued the Talented Tenth were capable of taking "these enslaved Israelites out of [their] still enduring bondage in short order." ${ }^{\prime 33}$ The Talented Tenth were of the highest order and past figures had included Ira Aldrige, Benjamin Banneker, David Walker, and Frederick Douglass. Du Bois combed through the history of black Americans to find illustrious figures that proved his point of black equality to inspire his own race, as it was to counter arguments of
${ }^{24}$ W.E.B. Du Bois, W.E.B. Du Bois: A Reader, ed. David Levering Lewis, (New York: Henry Holt, 1995), 33.

${ }^{25}$ W.E.B. Du Bois, "Black Folk and Birth Control," Birth Control Review, (June 1932), 166.

${ }^{26}$ Du Bois, Reader, 25.

${ }^{27}$ Ibid., 32.

${ }^{28}$ W.E.B. Du Bois, "Opinion," Crisis, (August 1922), 152-153.
${ }^{29}$ Gregory Michael Dorr and Angela Logan, "'Quality, Not Mere Quantity, Counts': Black Eugenics and the NAACP Baby Contests,"in A Century of Eugenics in America, ed. Paul A. Lombardo, (Bloomington: Indiana University Press, 2011), 72.

${ }^{30}$ W.E.B. Du Bois, "The Immediate Program of the American Negro," Crisis, (April 1915), 311.

${ }^{31}$ W.E.B. Du Bois, Writings by W.E.B. Du Bois in Nonperiodical Literature Edited by Others, ed. Herbert Aptheker. (Millwood: Kraus-Thomson, 1982), 20.

${ }^{32}$ W.E.B. Du Bois, "Black Folk and Birth Control," 166.

${ }^{33}$ Du Bois, Non-periodical, 220. 
blacks seeming non-commitment to science, art, and "civilization" that whites chose to ignore. The Talented Tenth were all to share similar characteristics of "intelligence, broad sympathy, knowledge of the world that was and is, and the relation of men to it. ${ }^{134}$ They were to be aware of themselves and their environment, to find the faults that plagued the African American community and to right those wrongs. Fighting against racism was a big part of the Talented Tenth; the lynching of African Americans in the South was an unforgivable offence but blacks had also to improve their own lot as a first means of defense against white racism. Du Bois saw the effect that poverty had on African Americans: women were "marching to hell" as prostitutes and black boys were being lured into "gambling and crime. ${ }^{\prime \prime 35}$ If, only by education, the black race could be "saved," then the Talented Tenth would become the rule and "lead all peoples to salvation." ${ }^{136}$

Du Bois had outright rejected any doctrine of racial supremacy as "inferior in judgment, knowledge and common sense. ${ }^{\prime \prime 37}$ The coming racial apocalypse would only come from whites' inability to acknowledge the African American as a person, not from blacks' supposed break from natural law. However, Du Bois' asserted efforts to topple white supremacy were complicated by his juxtaposition of superficially affirming an inferior black racial "essence" with a doctrine of racial uplift. He perceived the inflicted poverty on African Americans to be an outgrowth of a legacy of slavery, primarily in what he felt was an instilled deprivation of black intellectual thought. ${ }^{38}$ The "best and most capable" youth were encouraged to go into university to familiarize themselves with science and the arts to inspire more youth. ${ }^{39}$ Poverty was meaningless when faced by "the advance of eight thousand thousand

${ }^{34}$ Ibid., 17-18.

${ }^{35}$ Du Bois, A Reader, 25-26.

${ }^{36}$ Du Bois, Non-periodical, 196.

${ }^{37}$ W.E.B. Du Bois, "The Immediate Program of the

American Negro," Crisis, (April 1915), 310.

${ }^{38}$ Du Bois, A Reader, 26-27.

${ }^{39}$ Du Bois, Writings by W.E.B. Du Bois, 18 [sic] honest, earnest, inspired and united people."140 Education would free the collective shackles on the black consciousness. A continual push by African Americans to intellectualize themselves, regardless of class, would allow for a good "stock" to overcome the misery that was their parents' misfortune. Du Bois had thought that no African American was to be left behind: all must be a part or else the danger to black enlightened unity loomed constant. The lower strata of blacks worried Du Bois enough that he deemed education would not be enough to influence their heredity. Birth control looked to be the answers to Du Bois' prayers: Du Bois did not advocate for "selective breeding" or sterilization, any attempt spelled to conjure the memory of horrendous forced breeding practices in slavery. ${ }^{41}$

Class, however, did not guarantee the presence of good heredity, something that white eugenicists had argued. Middle-class African-Americans were accused of "[dosing] their children" with luxury to the point of negligence. Du Bois felt the cancellation of a children's publication, sponsored by the NAACP, and Crisis was indicative of middle-class apathy. The lack of subscription numbers brought his frustration to a boil that simmered into his column, "grown-ups are unbelievably stupid!" Du Bois believed that parents were in debt to their children; their offspring must be imbued with "health and strength," and even suggested that families should have no more and no less than two to three children. A woman to be found in excess was jeopardizing her health and that of her children and a man that was "careless" could hardly call himself a reliable husband. "Birth control is science," Du Bois pleaded, and science was moral. ${ }^{42}$ Despite the mistakes of the black middle-class, Du Bois had saved his wrath for the working class of African Americans. In 1932, nearly thirty years after his Talented Tenth proclamation, Du Bois held firm that the majority of blacks were the "least intelligent and fit, and least able to rear their children properly." The black church was to be held accountable in turning his Talented Tenth into a mockery. He blamed the continued lack of education and their reliance on religion, rather than science, on the lack of black empowerment, and, like a schoolteacher, he chided that "[impoverished African Americans] must learn that among human races and

$$
\begin{aligned}
& 4^{0} \text { Ibid., } 25 . \\
& { }^{41} \text { Dorr, Segregation's Science, } 158 . \\
& 4^{2} \text { Du Bois, "Opinion," 247-250. }
\end{aligned}
$$


groups, as among vegetables, quality and not mere quantity really counts." 43

Healthy children were regarded by Du Bois and Crisis as the mark of a thriving people. Well-nourished and "fit" babies adorned whole sections of the Crisis and, at times, a smiling toddler glossed the cover. Readers saw the reflection of an uplifted race, which was fit, well fed and well clothed, and presumably the offspring of a well educated parent. The new generation was to inspire the reader base: cheerful infants transitioned into assertive college graduates. The advertisements that were allowed print were for schools and centers for higher learning. W.E.B. Du Bois' own Fisk University and Howard University, with registration dates, beckoned the reader to do more than just read the publication; they had to apply it to their children. Most advertisements and many of the messages were directed towards boys and young men. The Daytona Normal and Industrial Institute for Negro Girls as "Just The Place For Your Girl" was an exception to the rule; Du Bois did not focus attention on the education of women. ${ }^{44}$ The Talented Tenth was labeled in strictly masculine terms, "with reasonable sacrifice, we can train to largest manhood." ${ }^{\prime 45}$ A woman's place was not to be neglected but it was her primary duty to ensure she does not bring "aimless rafts of children to the world." 46

W.E.B. Du Bois argued fervently for what he called "race organization." ${ }^{47}$ Black advancement was predicated on individual action that had to influence the whole. In addition, if there was no nurturing of "upright" character and education at home, a child had little hope of escaping destituteness. The ability of parents to take care of their children did not correlate with their income bracket, although Du Bois did think of the lower class as being genetically weaker. Marriage had to be built upon a mutual respect for both parties as well as that of the child, "any doctrine of marriage that conceives a quarrelling, unhappy, sordid and compulsory union of man, woman and children as better than peace and work even with poverty, is fundamentally wrong." The "educated Negro American" must have a blissful home with him as the upholder of "black virtues," supported by a wife who cooks and takes care of the children. ${ }^{48}$ It was this goal, which Du Bois called "Group I," that was upheld as the ideal outlined in his piece, The Philadelphia Negro. In ranking class in accordance with African-American life into four distinct categories, by order of their contribution to black progress, Du Bois created a measure of black "enlightenment" that corresponded with his message. ${ }^{49}$

On an institutionalized level, "race organization" meant the establishment of "Negro colleges, Negro newspapers, Negro business organizations, a Negro school of literature and art, and an intellectual clearing house," which he deemed the "Negro Academy." ${ }^{\circ}$ Black representation meant the counter-voice to white scientific racism, a threat to the widely-held belief of blacks' "innate" and "inferior" capabilities. It also meant that African Americans would grow to see themselves as persons of equal intellect. It ensured the "realization of that broader humanity," that whites would be forced to concede the races are all of "one flesh." The pressures put on African Americans were immense. Unlike their white peers, black fulfillment meant an actual effort to turn away from "madness." Whites lived comfortably, knowing that they were a superior people based on their heredity alone. For blacks, by striving for socioeconomic and political enfranchisement, reliance on any form of biological determinism equated "race suicide." The gauge of black success was predicated on the success of their children by how they raised them and on their actions to bring education inside and outside their home. To do no less was to surrender to poverty and their "heritage from slavery."

The corresponding black eugenics movement took from mainstream eugenics one further method of promoting their message: baby contests. The NAACP was able to total $\$ 80,000$ between 1924 and 1930 from parents entering their children into these competitions. ${ }^{51}$ Children entered into

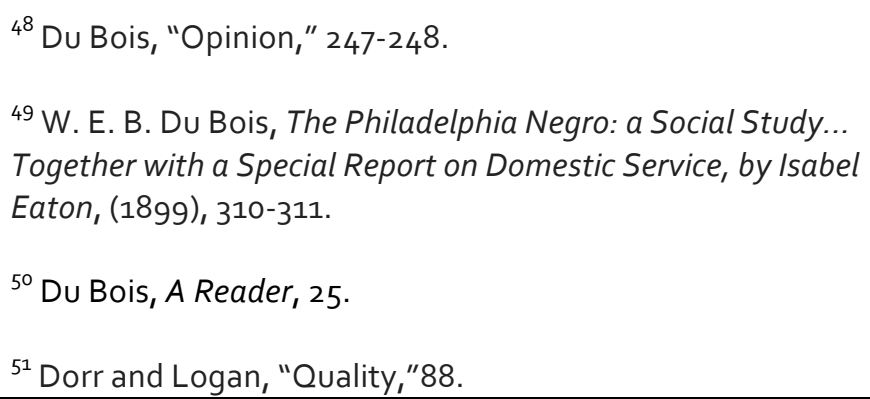

\begin{tabular}{ll}
${ }^{43}$ Du Bois, "Black Folk and Birth Control," $166-167$. & 48 Du Bois, "Opinion," $247-248$. \\
${ }^{44}$ Du Bois, "Opinion," $148-150$. & ${ }^{49}$ W. E. B. Du Bois, The Philadelphia Negro: a Social Study... \\
${ }^{45}$ Du Bois, "Black Folk and Birth Control," 166-167. & $\begin{array}{l}\text { Together with a Special Report on Domestic Service, by Isabel } \\
\text { Eaton, (1899), 310-311. }\end{array}$ \\
${ }^{46}$ W.E.B. Du Bois, "Editorial." Crisis, (October 1912), 287. & ${ }^{50}$ Du Bois, A Reader, 25. \\
${ }^{47}$ Du Bois, A Reader, 25. & ${ }^{51}$ Dorr and Logan, "Quality,"88. \\
\hline
\end{tabular} University of Saskatchewan Undergraduate Research Journal 
these contests were to represent "sound black reproduction." Regional contest finalists were eligible to enter the nationals and their pictures were printed in the next issue of The Crisis. The primary focus was to promote the NAACP's anti-lynching "crusade" by getting what Du Bois termed, "healthy human babies. ${ }^{1{ }^{2}}$ Race was separated from the rhetoric; the reader was to see not only a black child but also a fledgling human being. Mainstream eugenicists had used racial rhetoric in order to imbue perceptions of inborn hereditary inequality. By flirting with eugenic theory (albeit in a modified form), Du Bois presented each child as potentially representative of the Talented Tenth and hence able to break from the common racial trajectory of poverty and possible premature death put on blackness as a whole.

\section{Conclusion}

The beleaguered plight of lower-class African Americans was almost entirely overlooked by both black and white "agents of eugenics" in their zealotry. Between 1882 and 1944, approximately 4,700 African Americans were lynched and countless more had their lives directed by the omnipotent shadow of racism. ${ }^{53}$ Their lives were to be cheap in value and their bodies were to be the fault that all others must guide themselves against. Du Bois' continued philosophical refinement ran him into trouble with the NAACP board, which felt he was not "in general agreement with that of the organization. ${ }^{154}$ From 1910 to 1934, Du Bois was the man behind the NAACP and the Crisis publication, and still by 1948 he had stood by his creed of eugenic-based racial purity. The Talented Tenth was to become the "Guiding Hundredth," which attempted to make his position more inclusive as it tried to show the urgency of building greater numbers of individual betterment. W.E.B. Du Bois did not waiver in his convictions; he was a student of the 1900s, a product of his time. ${ }^{55}$

-




\section{Bibliography}

Dorr, Gregory Michael. Segregation's Science: The American Eugenics Movement and Virginia. Charlottesville: University of Virginia Press, 2008.

Dorr, Gregory Michael and Angela Logan. A Century of Eugenics in America. Edited by Paul A. Lombardo. Bloomington: Indiana University Press, 2011.

Du Bois, W.E.B. "Black Folk and Birth Control." Birth Control Review, June 1932, 166-167.

Du Bois, W.E.B. W.E.B. Du Bois: A Reader. Edited by David Levering Lewis. New York: Henry Holt, 1995.

Du Bois, W.E.B. Writings by W.E.B. Du Bois in Non-periodical Literature Edited by Others. Edited by Herbert Aptheker. Millwood: Kraus-Thomson, 1982.

Du Bois, W.E.B. "Editorial." Crisis, October 1912, 287-291.

Du Bois, William Edward Burghardt. The Philadelphia Negro: a Social Study... Together with a Special Report on Domestic Service, by Isabel Eaton. 1899.

Du Bois, W.E.B. "The Immediate Program of the American Negro." Crisis, April 1915, 310-312.

Du Bois, W.E.B. "Opinion." Crisis, August 1922, 148-153.

Du Bois, W.E.B. "Opinion." Crisis, October 1922, 247-250.

O'Brien, Gerald V. Framing the Moron: The Social Construction of Feeble-mindedness in the American Eugenic Era. Manchester: Manchester University Press, 2013.

Selden, Steven. Transforming Better Babies into Fitter Families: Archival Resources and the History of the American Eugenics Movement, 1908-1930. Proceedings of the American Philosiophical Society, 2005 . 
